\title{
STRUCTURE AND FUNCTION OF FIBRINOGEN BßN-DOMAINS
}

\author{
L. MEDVED $\bowtie, S . Y A K O V L E V$ \\ Center for Vascular and Inflammatory Diseases and Department of Biochemistry and \\ Molecular Biology, University of Maryland School of Medicine, Baltimore, MD, USA; \\ 凶e-mail:Lmedved@som.umaryland.edu
}

Received: 17 May 2020; Accepted: 30 June 2020

\begin{abstract}
Fibrinogen is a polyfunctional plasma protein involved in various physiological and pathological processes through the interaction of its multiple domains with different ligands and cell receptors. Among fibrinogen domains, two $B \beta N$-domains are formed by the $N$-terminal portions of its two $B \beta$ chains including amino acid residues B B1-64. Although their folding status is not well understood and the recombinant disulfidelinked (B $\beta 1-66)_{2}$ fragment corresponding to a pair of these domains was found to be unfolded, some data suggest that these domains may be folded in the parent molecule. In contrast, their major functional properties are well established. Removal of fibrinopeptides B (amino acid residues B B1-14) from these domains upon fibrinogen to fibrin conversion results in the exposure of multiple binding sites in fibrin $\beta N$-domains (residues $\beta 15-64)$. These sites provide interaction of the $\beta N$-domains with different proteins and cells and their participation in various processes including fibrin assembly, fibrin-dependent angiogenesis, and fibrindependent leukocyte transmigration and thereby inflammation. The objective of this review is to summarize the current view of the structure and function of these domains in fibrinogen and fibrin and their role in the above-mentioned processes.
\end{abstract}

Ke ywo rds: fibrinogen, fibrin $\beta N$-domains, heparin, VE-cadherin, VLDL receptor.

\section{Introduction}

Fibrinogen is the critical component of the haemostatic system. Its major function is to polymerize upon conversion into fibrin to form a fibrin clot, which is the major constituent of a blood clot. Blood clots seal damaged vasculature thereby preventing blood loss. Thrombin-mediated conversion of fibrinogen to fibrin results in the exposure of multiple binding sites that enable its interaction with different proteins and cell types and subsequent participation of fibrin in fibrinolysis, wound healing, atherogenesis, tumorigenesis, and other important physiological and pathological processes. This polyfunctional character of the fibrinogen molecule is connected with its multidomain structure in which each fibrin(ogen) domain or combination thereof may participate in certain interactions and thereby carry out certain functions. Studying the structure and function of individual fibrinogen domains is an important step towards a more comprehensive un- derstanding of how this polyfunctional molecule participates in multiple processes. This review summarizes the major findings about the structure and function of the fibrinogen $\mathrm{B} \beta \mathrm{N}$-domains.

\section{Structure of fibrinogen B $\beta N$-domains}

The fibrinogen molecule consists of two identical subunits, each of which is composed of three non-identical polypeptide chains, $\mathrm{A} \alpha, \mathrm{B} \beta$, and $\gamma$, linked together by 28 disulfide bonds [1] (Fig., A). The letters " $\mathrm{A}$ " and " $\mathrm{B}$ " in the $\mathrm{A} \alpha$ and $\mathrm{B} \beta$ chains designate the $\mathrm{N}$-terminal fibrinopeptides $\mathrm{A}$ and $\mathrm{B}$, respectively, that are removed by thrombin upon conversion of fibrinogen into fibrin $[1,2]$. The Nterminal portions of all six fibrinogen chains come together to form the central $\mathrm{E}$ region while the Cterminal portions of these chains form two identical terminal $\mathrm{D}$ regions [2]. These regions are arranged in the molecule linearly in a D-E-D manner. All of these chains are folded into at least 20 distinct

(C) 2020 Medved L., Yakovlev S. This is an open-access article distributed under the terms of the Creative Commons Attribution License, which permits unrestricted use, distribution, and reproduction in any medium, provided the original author and source are credited. 
A

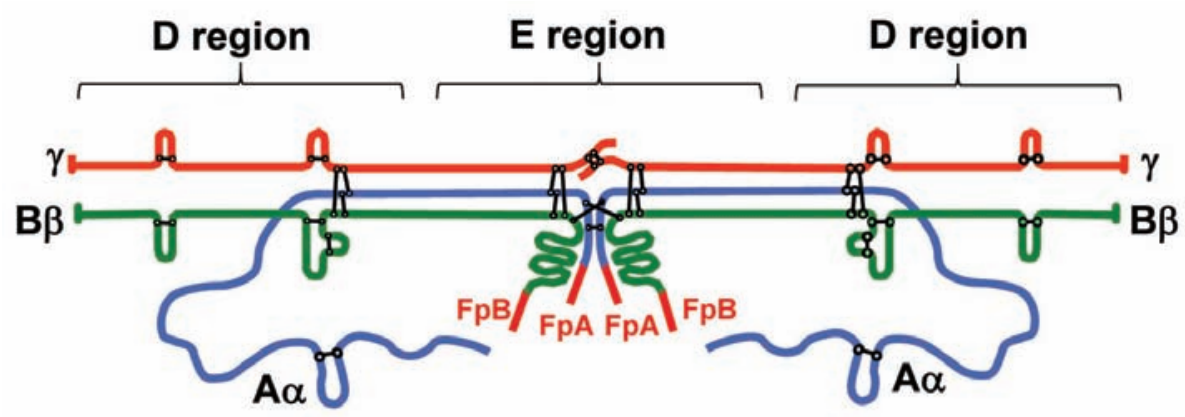

B

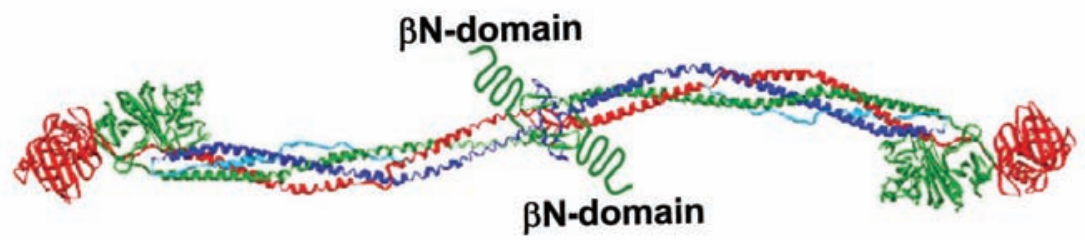

C

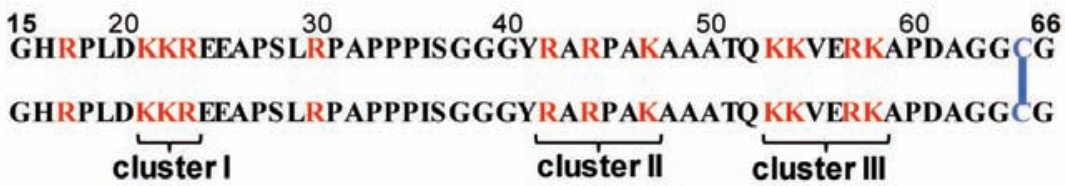

Structures of the fibrinogen molecule and fibrin $\beta N$-domains. (A) Polypeptide chain composition of fibrinogen. The individual chains, $A \alpha, B \beta$ and $\gamma$, are colored in blue, green, and red, respectively; fibrinopeptides $A$ and $B$ (FpA and FpB, respectively) are in red; disulfide bonds are represented by black bars. (B) Ribbon diagram of the fibrinogen molecule based on its crystal structure [14]. Fibrin $\beta N$-domains, whose location is arbitrary, are shown schematically by two green wavy lines. (C) The amino acid sequence of the dimeric disulfide-linked (B15-66) ${ }_{2}$ fragment corresponding to a pair of fibrin $\beta N$-domains. The disulfide bond Cys65-Cys65 is shown schematically by a blue vertical line. Positively charged Lys $(K)$ and Arg $(R)$ amino acid residues are shown in red, and the three clusters (I, II, III) of positively charged residues are indicated

domains which were originally identified by differential scanning calorimetry [3-6], and then confirmed by numerous X-ray studies [7-14] (Fig., B). The X-ray studies established the 3D structure of human, bovine, and chicken fibrinogen molecules [9-11, 14]. However, the C-terminal portions of the $\mathrm{A} \alpha$ chains and $\mathrm{N}$-terminal portions of the $\mathrm{B} \beta$ chains corresponding to the fibrinogen $\alpha \mathrm{C}$ - and $\mathrm{B} \beta \mathrm{N}$ domains were not visible in the electron density maps [14], raising questions about the folding status of these regions in the fibrinogen molecule. While the 3D structures of bovine and human fibrinogen $\alpha \mathrm{C}$-domains had been established by NMR studies and molecular modelling [15-17], that of the BßNdomains remained unclear.

Each of the two fibrinogen $\mathrm{B} \beta \mathrm{N}$-domains includes $B \beta$ chain residues $\beta 1-64$ attached to the bulk of the molecule through a $\beta$ Cys $65-\alpha$ Cys 36 disulfide bond. According to the proposed nomenclature [2], in fibrin, in which fibrinopeptides B are removed by thrombin, these domains encompass residues $\beta 15$ 64 and are called $\beta \mathrm{N}$-domains. The crystal structure of human and bovine fibrinogens and their $\mathrm{E}$ fragments, whose overall folds are similar [14], revealed that these two disulfide bonds are located in the central region of the molecule very close to each other. Based on these findings, we prepared a recombinant dimeric (B $\beta 1-66)$, fragment in which two identical B $\beta 1-66$ chains, each corresponding to the $\mathrm{B} \beta \mathrm{N}$-domain, are linked together through a Cys65Cys65 disulfide bond (Fig., $C$ ) and which mimics the dimeric arrangement of the $\mathrm{B} \beta \mathrm{N}$-domains in the fibrinogen molecule [18]. We also prepared a recombinant dimeric ( $\beta 15-66)_{2}$ fragment by treatment of $(B \beta 1-66)_{2}$ with thrombin, which removes fibrinopeptides B [18]. This fragment corresponds to a pair of fibrin $\beta \mathrm{N}$-domains. Our experiments performed using circular dichroism and differential scanning 
calorimetry techniques revealed no folded structures in both dimeric fragments indicating that they are unordered in solution [18]. However, this does not mean that the $\mathrm{B} \beta \mathrm{N}$-domains are unordered in the fibrinogen molecule. In this connection, secondary structure prediction and computer modelling of the structure of the $\beta 1-55$ and $\beta 15-55$ sequences encompassing most of the fibrinogen $\mathrm{B} \beta \mathrm{N}$ - and fibrin $\beta \mathrm{N}$-domains, respectively, revealed a possibility of secondary and tertiary structure formation by these regions [19]. Namely, it was predicted that $\mathrm{B} \beta 6-13$, $\beta 19-26$, and $\beta 43-55$ portions of the $\mathrm{B} \beta \mathrm{N}$-domain may form $\alpha$-helices that could be folded into certain tertiary structures and removal of fibrinopeptide B from this domain may result in a dramatic change in conformation [19]. In agreement, the results of computer modelling of the $B \beta 1-60$ and $\beta 15-60$ regions and limited proteolysis of the $\mathrm{B} \beta 42-43$ peptide bond performed by another group [20] also predict some folded conformations in the (B) $\beta \mathrm{N}$-domains.

Thus, although there is no experimental evidence confirming these predictions, one can speculate that these domains may be folded in the intact molecules where their structure can be stabilized by interactions with the neighboring regions. In agreement with this speculation, a previous study showed interaction between fibrinogen $\alpha \mathrm{C}$-domains and $\mathrm{B} \beta \mathrm{N}$-domains in which fibrinopeptides B play a significant role [21]. Additional studies with the whole fibrinogen molecule and the $\mathrm{E}_{1}$ fragment derived from the central region of fibrin are needed to test this conjecture.

\section{Role of fibrinogen BßN- domains in fibrin assembly}

The functional properties of the (B) $\beta \mathrm{N}$-domains in fibrinogen and fibrin were extensively studied and some of their major functions were established. For example, their role in the fibrin assembly process is well known. Although fibrin polymerization can occur after the removal of only fibrinopeptides A [22], this type of fibrin has an altered structure and resistance to fibrinolysis [23-25]. Thus, the removal of fibrinopeptides B is important for formation of a normal fibrin clot [26].

It is now widely accepted that fibrin polymerization occurs through the interaction between two pairs of complementary polymerization sites called holes 'a' and 'b' and knobs ' $\mathrm{A}$ ' and 'B', which are located in the C-terminal $\mathrm{D}$ and central $\mathrm{E}$ regions, respectively [27]. The ' $a$ ' and ' $b$ ' sites (holes) in the
$\mathrm{D}$ regions are always exposed while the complementary ' $\mathrm{A}$ ' and 'B' sites (knobs) in the E region are protected by fibrinopeptides A and B. Proteolytic removal of these fibrinopeptides with thrombin results in the exposure of the 'A' and 'B' knobs and subsequent 'A'-'a' and 'B'-'b' (knob-to-hole) interactions that lead to the formation of fibrin polymer [2, 27]. Since the two pairs of 'A' and B' knobs are located in the central $\mathrm{E}$ region and the complementary ' $\mathrm{a}$ ' and ' $b$ ' holes are in the terminal D regions, this interaction is often called DD:E (or D:E:D) interaction in which the $\mathrm{E}$ region of one fibrin molecule interacts with the $\mathrm{D}$ regions of two neighboring fibrin molecules. The 'a' and 'b' holes are represented by socalled polymerization pockets, whose structure was well characterized by crystallographic studies $[7,8$, 28], while the ' $\mathrm{A}$ ' and ' $\mathrm{B}$ ' knobs are represented by Gly-Pro-Arg and Gly-His-Arg sequences, respectively, exposed after removal of fibrinopeptides A and $B$ from the fibrinogen $A \alpha$ and $B \beta$ chains $[27,29$, 30]. Thus, fibrin $\beta \mathrm{N}$-domains contain Gly-His-Arg knobs which are involved in the ' $\mathrm{B}$ '-' $\mathrm{b}$ ' knob-to-hole interaction. However, this is not the only function of the $\beta \mathrm{N}$-domains in the fibrin assembly process.

Fibrin assembly is a highly ordered process which occurs in two stages. It was shown by Blombäck and collaborators that fibrinopeptides A and B are removed by thrombin in a sequential manner and the sequential release of these fibrinopeptides results in sequential activation of two sets of polymerization sites [31]. In the first stage, removal of fibrinopeptides A results in 'A'-'a' interaction between the $\mathrm{D}: \mathrm{E}: \mathrm{D}$ regions and formation of two-stranded protofibrils [32]. In the second stage, protofibrils aggregate laterally resulting in thicker fibrils, which form a 3D fibrin network [32]. This process coincides with the removal of fibrinopeptides B. Further, it was shown that the release of fibrinopeptides B, which is very slow at the start of the reaction, is accelerated upon polymer formation [31, 33-35]. Although the exact molecular mechanism underlying such sequential cleavage of fibrinopeptides is not completely understood, it is accepted that nonsubstrate interaction of thrombin with fibrinogen, which occurs before proteolytic cleavage of fibrinopeptides, plays an important role in both stages. After establishing the crystal structure of thrombin in complex with the E fragment [13], which represents the central region of fibrin molecule, it became clear that fibrinopeptide A-containing portions of fibrinogen $A \alpha$ chains are located in the vicinity of 
two molecules of bound thrombin and, therefore, their fibrinopeptides A are better positioned than fibrinopeptides B to be cleaved first by thrombin [36]. Further, our experiments showed that the (B $\beta 1-66)_{2}$ fragment, representing a pair of fibrinogen $B \beta N-$ domains, interacts with the dimeric crosslinked D-D fragment with a greater than 10 -fold higher affinity than with the monomeric D fragment $\left(K_{d}\right.$ of $13 \mu \mathrm{M}$ vs $153 \mu \mathrm{M}$ ) [36], suggesting that such an interaction may play a role in the orientation of fibrinopeptides B towards the active site of thrombin. Indeed, molecular modeling of the fibrin protofibril with bound thrombin revealed that such an interaction may direct fibrinopeptides B towards active sites of two bound thrombin molecules for efficient cleavage [36]. This modeling result is in good agreement with previous findings that fibrinopeptide $\mathrm{B}$ release is accelerated upon polymer formation [31, 33-35]. Thus, fibrinogen $\mathrm{B} \beta \mathrm{N}$-domains not only donate knobs ' $\mathrm{B}$ ' for ' $\mathrm{B}$ '-' $\mathrm{b}$ ' interaction but also interact with the DD regions in protofibrils to accelerate the removal of fibrinopeptides B by thrombin.

\section{Interaction of fibrinogen $\mathrm{B} \beta \mathrm{N}$ - domains with heparin}

A second important function of fibrinogen $\mathrm{B} \beta \mathrm{N}$-domains is their interaction with heparin. Heparin is a structural analogue of heparan sulfate found on the surface of most cells and in the extracellular matrix $[37,38]$. Heparan sulfate-containing proteoglycans anchored to cell surfaces play an important role in various biological processes $[37,38]$. Heparin and heparan sulfate both belong to the glycosaminoglycan family and are represented by a mixture of linear, highly sulfated, and negatively charged polysaccharide chains of different lengths [39, 40]. Since fibrin $\beta \mathrm{N}$-domains contain several positively charged residues grouped into three positively charged clusters (Fig., C), it is not surprising that they interact with heparin and proteoglycans due to electrostatic attraction between opposite charges. Heparin, which was found in mast and some hematopoietic cells $[41,42]$, is widely used as an anticoagulant due to its ability to interact with antithrombin III and thrombin and to enhance thrombin inhibition by antithrombin III $[42,43]$. At the same time, heparin forms a ternary complex with thrombin and fibrin $[44,45]$ in which thrombin is markedly protected from inactivation by heparin-antithrombin III while maintaining its activity toward fibrinogen [45-48]. Thus, interaction of fibrin with heparin plays an important role in modulation of thrombin activity. It was also reported that the $\beta 15-42$ sequence of fibrin representing a portion of the fibrin $\beta \mathrm{N}$-domain mediates heparindependent binding of fibrin to endothelial cell surface proteoglycans [49]. The functional role of this binding remains to be elucidated.

Interaction of heparin with fibrinogen and fibrin was demonstrated in several studies $[45,50$ 53]. The first attempt to localize heparin-binding sites in fibrinogen was performed by Mohri et al. [54] who found two heparin-binding fragments derived from the fibrinogen D region. In agreement, Raut and Gaffney [52] reported that fibrinogen fragment $\mathrm{D}$ bound to heparin, while no binding was observed with fragment E. In contrast, Odrljin et al. [53] localized heparin-binding sites of fibrinogen and fibrin in the 1-42 and 15-42 portions of their $\mathrm{B} \beta$ and $\beta$ chains, respectively. They also found that fibrin binds to heparin with a 3.5-fold higher affinity than does fibrinogen [53]. It should be noted that there are two major plasmin cleavage sites in the fibrinogen $\mathrm{B} \beta \mathrm{N}$-domain, at $\beta \mathrm{Arg} 42-\mathrm{Ala} 43$ and $\beta$ Lys53-Lys54 [1], and that B $\beta 1-42$ and $\beta 15-42$ fragments are naturally occurring plasmin degradation products of fibrinogen and fibrin, respectively. These fragments can be easily prepared from plasmin digest of fibrin(ogen) [55] or synthesized. In addition, a specific protease III from the venom of the western diamondback rattlesnake purified in the laboratory of Dr. A. Budzynski cleaves only the $\beta 1-42$ portions of fibrinogen $\mathrm{B} \beta$ chains resulting in so-called fibrinogen 325 [56-58]. Fibrinogen 325, as well as the B $\beta 1-42$ and $\beta 15-42$ fragments, have been used in experiments resulting in localization of the heparinbinding site to the fibrin(ogen) $\mathrm{B} \beta 1-42$ and $\beta 15-42$ regions [53] and in other experiments described elsewhere in this review.

To clarify the contradictory results described above and to further localize the heparin-binding site in fibrino(gen), we performed a detailed study of the interaction of heparin with fibrinogen, fibrin, and their various fragments including the recombinant (B $\beta 1-66)_{2}$ and ( $\left.\beta 15-66\right)_{2}$ fragments corresponding to a pair of fibrinogen $\mathrm{B} \beta \mathrm{N}$ - and fibrin $\beta \mathrm{N}$-domains, respectively [59]. The results showed that the (B) $\beta N$-domains are the only domains in fibrin(ogen) that bind heparin, in agreement with the previous study [53]. However, in contrast to this study, which localized the heparin-binding site of fibrin to the $\beta 15-42$ region [53], we found that the full-length $\beta \mathrm{N}$-domain fragment, either monomeric or dimeric, 
has higher affinity to heparin than the $\beta 15-42$ fragment [59]. This finding indicates that the third positively charged cluster of fibrin $\beta \mathrm{N}$-domain (Fig., $C$ ) is also involved in heparin binding. We also found that removal of fibrinopeptides B from fibrinogen $\mathrm{B} \beta \mathrm{N}$-domains results in a 3-fold increase of heparin affinity to these domains (the $K_{d}$ value is decreased from 228 to $72 \mathrm{nM}$ ) [59], in accord with the previous finding [53]. Further, we found that the affinity of the dimeric ( $\beta 15-66)_{2}$ fragment to heparin is much higher than that of the monomeric $\beta 15-64$ fragment (the determined $K_{d}$ values were $66 \mathrm{nM}$ for $(\beta 15-66)_{2}$ and $7.1 \mu \mathrm{M}$ for $\beta 15-64)$ and is comparable to that of fibrin and the $E_{1}$ fragment $\left(K_{d}=72\right.$ and $70 \mathrm{nM}$, respectively) [59]. These findings suggest that the heparinbinding site in fibrin(ogen) is formed by a pair of the (B) $\beta \mathrm{N}$-domains. They also indicate that the dimeric $(\mathrm{B} \beta 1-66)_{2}$ and ( $\left.\beta 15-66\right)_{2}$ fragments mimic well the heparin-binding properties of fibrinogen and fibrin, respectively.

Thus, the results of the studies described above revealed the following facts. First, the major, and probably the only, physiologically relevant heparinbinding site in fibrinogen is located in its central $\mathrm{E}$ region, namely, in its $\mathrm{B} \beta \mathrm{N}$-domains. Second, the dimeric arrangement of these domains is critical for formation of the fully active heparin-binding site in both fibrinogen and fibrin. Third, conversion of fibrinogen to fibrin results in a 3-fold increase in the affinity of these domains to heparin. Finally, all three positively charged clusters of Lys/Arg residues in the (B) $\beta \mathrm{N}$-domains (Fig., $C$ ) are involved in the interaction with heparin. The individual Lys and Arg residues that are critical for binding of heparin to fibrin(ogen) remain to be established.

\section{Interaction of fibrin $\boldsymbol{\beta N}$-domains with vascular endothelial (VE)-cadherin and its role in fibrin-dependent angiogenesis}

A third important function of fibrin $\beta \mathrm{N}$ domains is their interaction with vascular endothelial (VE)-cadherin, a member of the cadherin family of homophilic cell-cell adhesion receptors with a typical modular structure that includes five homologous extracellular domains, as well as cytoplasmic and transmembrane domains [60]. This interaction promotes angiogenesis (formation of new blood vessels) [61], which plays an important role in wound healing, tissue repair, tumorigenesis, and some cardiovascular diseases [62-65]. Although the ability of fibrin gel to support capillary growth was reported several decades ago [66, 67], this function has been studied more recently and described in detail by Dr. J. Martinez and collaborators [61]. First, they studied the formation of capillary tubes by endothelial cells sandwiched between two fibrin gels under serumfree conditions and observed maximal tube formation with fibrin desAABB, minimal tube formation with fibrin desAA, and complete absence of tube formation with fibrin 325 desAA, which lacks the $\mathrm{N}$-terminal $\beta 15-42$ sequence [68]. They also found that the addition of the $\beta 15-42$ fragment significantly reduced the number and length of the tubes [68]. Based on these findings, they suggested that the $\beta 15$ 42 sequence of fibrin interacts with a component on the endothelial surface and this interaction plays a fundamental role in the induction of endothelial capillary tube formation [68]. Next, they demonstrated that a monoclonal antibody against human VE-cadherin inhibited formation of capillary tubes by endothelial cells sandwiched between fibrin gels [69]. Finally, they identified endothelial cell VE-cadherin as a receptor for fibrin which interacts with its $\beta 15$ 42 sequence and demonstrated that this interaction requires removal of fibrinopeptides $B$ to expose this sequence [70]. It should be noted that although the $\beta N$-domains of fibrin are involved in the ' $B$ '- $b$ ' interaction, experiments with the monoclonal antibody T2G1 recognizing the fibrin $\beta 15-21$ sequence showed that about $14 \%$ of these sequences are recognized by this antibody [71]. This finding indicates that at least part of fibrin $\beta \mathrm{N}$-domains in fibrin polymers are available for interaction with VE-cadherin and other ligands and receptors.

VE-cadherin represents membrane-anchored adhesive molecules located at the endothelial intercellular junctions [72]. They are anchored to the cytoskeleton through their cytoplasmic domains while their extracellular portions, each consisting of five homologous domains, are involved in homophilic interaction with VE-cadherins of neighboring molecules thereby mediating cell-cell interaction and contributing to the integrity of the endothelium $[72,73]$. Fibrin was the first heterophilic ligand identified for VE-cadherin [70]. Thus, the discovered heterophilic interaction of VE-cadherin with fibrin, which promotes fibrin-dependent angiogenesis [61], expands the functional properties of VE-cadherin beyond its adhesive function.

To clarify the molecular mechanism of heterophilic interaction between fibrin and VE-cadherin, we expressed the VE-cadherin fragment corre- 
sponding to four extracellular N-terminal domains of VE-cadherin, VE-cad(1-4) fragment, and a number of $\beta \mathrm{N}$-domain fragments containing the $\beta 15-42$ sequence, and tested interactions between them [18]. The experiments demonstrated that only the dimeric $(\beta 15-66)_{2}$ fragment bound to the VE-cad(1-4) fragment with high affinity $\left(K_{\mathrm{d}}=80 \mathrm{nM}\right)$, while the monomeric $\beta 15-42$-containing fragments exhibited no binding at concentrations up to $400 \mathrm{nM}$ [18]. As in the case with heparin-binding [59] described above, the affinity of ( $\beta 15-66)_{2}$ to VE-cad(1-4) was very similar to that of fibrin to VE-cad(1-4) $\left(K_{\mathrm{d}}=80\right.$ and $69 \mathrm{nM}$, respectively) [18], indicating that the dimeric $(\beta 15-66)_{2}$ completely preserves the VE-cadherinbinding properties of fibrin $\beta \mathrm{N}$-domains. Further, we mutated several residues in the N-terminal portions of the dimeric ( $\beta 15-66)_{2}$ fragment and found that His16 and Arg17 are critical for the high affinity binding to occur [18]. We also localized the complementary fibrin-binding site within the third extracellular domain of VE-cadherin [74].

Thus, the studies described above showed that interaction of fibrin with endothelial cell VEcadherin promotes capillary tube formation, i.e. angiogenesis, which occurs during normal wound healing or neovascularization during tumor growth and metastasis $[61,68]$. This interaction requires the removal of fibrinopeptides B from fibrinogen and occurs through a pair of fibrin $\beta \mathrm{N}$-domains and the third extracellular domain of VE-cadherin $[18,70$, 74]. The N-terminal His16 and Arg17 residues of fibrin $\beta \mathrm{N}$-domains are critical for the interaction [18]. However, one should also consider that other $\beta \mathrm{N}$ domain residues may be involved in this interaction. This possibility needs to be investigated. Additional studies are also required to further clarify exactly how the interaction of fibrin with VE-cadherin promotes angiogenesis.

It should be noted that interaction of fibrin $\beta \mathrm{N}$-domains with VE-cadherin was also implicated in fibrin-dependent inflammation. Namely, it was proposed that the interaction of the fibrin degradation product $\mathrm{E}_{1}$ fragment, which contains these domains, with VE-cadherin promotes transendothelial migration of leukocytes and thereby inflammation, and the $\beta 15-42$ fragment significantly reduces leukocyte transmigration by inhibiting this interaction $[75,76]$. We later confirmed the inhibitory properties of the $315-42$ fragment on leukocyte transmigration and found that the dimeric version of this fragment, $(\beta 15-44)_{2}$, is a superior inhibitor over $\beta 15-42$ and exhibits significant anti-inflammatory properties and cardioprotective effect in in vivo mouse models [77]. However, our recent study [78] revealed that $\beta 15-42$ cannot inhibit the $\mathrm{E}_{1}$ fragment-VE-cadherin interaction due to its very low affinity for VE-cadherin. Its inhibitory effect on leukocyte transmigration most likely occurs through a putative endothelial receptor which remains to be identified.

\section{Interaction of fibrin $\boldsymbol{\beta} \mathbf{N}$-domains with the very low density lipoprotein (VLDL) receptor and its role in fibrin-dependent inflammation}

Another important interaction of fibrin $\beta \mathrm{N}$ domains, which is involved in the inflammatory response, was discovered more recently. We found that fibrin and some of its degradation products interact with the very low density lipoprotein (VLDL) receptor on endothelial cells and that this interaction promotes fibrin-dependent leukocyte transmigration $[79,80]$. We also found that the fibrin-VLDL receptor interaction occurs through fibrin $\beta \mathrm{N}$-domains [79] and all three positively charged clusters of these domains (Fig., C) are involved in this interaction [81]. The complementary fibrin-binding site was localized to the second and third cysteine-reach (CR) domains of the VLDL receptor while the presence of its fourth CR domain, although not required for the binding, increases the affinity of this binding by about 2-fold [82]. The structure of the fibrin-binding fragment of the VLDL receptor, VLDLR(2-4), containing these three CR domains, has been established by NMR [83]. Finally, we clarified the molecular mechanism by which the fibrin-VLDL receptor interaction promotes leukocyte transmigration [78]. This mechanism includes interaction of fibrin with the VLDL receptor located on endothelial cells which triggers the VLDL receptor-dependent pathway of leukocyte transmigration inside the cells resulting in inhibition of the Src kinase Fyn [78]. The inhibition of Fyn prevents inhibition of GTPase protein RoA, which in the active state increases endothelial junction permeability $[84,85]$ resulting in increased leukocyte transmigration.

The discovery of the fibrin-VLDL receptordependent pathway of leukocyte transmigration and thereby inflammation prompted us to search for efficient inhibitors of this pathway. Our search resulted in identification of two monoclonal antibodies, $\mathrm{mAb}$ $1 \mathrm{H} 5$ and $\mathrm{mAb} 1 \mathrm{H} 10$, which inhibited fibrin-VLDL receptor interaction and significantly reduced fibrindependent leukocyte transmigration [86]. These 
monoclonal antibodies were prepared earlier against the VLDL receptor in the laboratory of Dr. D. Strickland [87]; however, their inhibitory functions towards the fibrin-VLDL receptor interaction were not tested. After establishing that the epitopes for these antibodies overlap with the fibrin-binding site of the VLDL receptor [86], we realized that they can be used for inhibition of the fibrin-VLDL receptordependent pathway. Indeed, in a mouse model of peritonitis, in which leukocyte infiltration into the peritoneum is stimulated by injection of the proinflammatory agent thioglycollate, both monoclonal antibodies inhibited this infiltration by almost $50 \%$, indicating their significant anti-inflammatory properties [86]. In addition, both antibodies exhibited a significant cardioprotective effect in a mouse model of myocardial ischemia-reperfusion injury [86]. Thus, these two antibodies are potent inhibitors of the fibrin-induced VLDL receptor-dependent pathway of leukocyte transmigration.

In summary, although the structures of the $\mathrm{B} \beta \mathrm{N}$ - and $\beta \mathrm{N}$-domains in fibrinogen and fibrin are still unclear, one can consider the possibility that they are folded in the fibrinogen molecule due to interactions with the neighboring structures and may unfold upon conversion of fibrinogen to fibrin to expose their binding sites for interaction with their ligands and receptors. These domains are multifunctional, i.e. they are involved in various (patho) physiological processes. It is now well established that they participate in the fibrin assembly process, interact with heparin, VE-cadherin, and the VLDL receptor. Their interaction with heparin is involved in modulation of thrombin activity. In addition, they interact with cell surface proteoglycans whose identity and functions remain to be determined. Interaction of fibrin with VE-cadherin, which occurs exclusively through fibrin $\beta \mathrm{N}$-domains, promotes fibrin-dependent angiogenesis. The exact molecular mechanism underlying this process remains to be established. Finally, interaction of fibrin with the VLDL receptor through its $\beta \mathrm{N}$-domains triggers the fibrin-VLDL receptor-dependent pathway of leukocyte transmigration which is involved in the inflammatory response in normal and pathological states. The molecular mechanism of this pathway has been clarified; however, putative intermediates of this pathway remain to be identified. Importantly, the two monoclonal antibodies, $\mathrm{mAb} 1 \mathrm{H} 5$ and $\mathrm{mAb}$ $1 \mathrm{H} 10$, identified as efficient inhibitors of this pathway could possibly be developed as potent therapeu- tics for treatment of fibrin-dependent inflammationrelated cardiovascular diseases.

Conflict of interest. Authors have completed the Unified Conflicts of Interest form at http://ukrbiochemjournal.org/wp-content/uploads/2018/12/coi_ disclosure.pdf and declare no conflict of interest.

Acknowledgements. This work was supported by the National Institutes of Health grant HL 56051 to L. Medved.

\section{СТРУКТУРА І ФУНКЦЇ̈ ВßN-ДОМЕНІВ ФІБРИНОГЕНУ}

\author{
Л. Медвідь \\ Center for Vascular and Inflammatory \\ Diseases and Department of Biochemistry and \\ Molecular Biology, University of Maryland \\ School of Medicine, Baltimore, MD, USA; \\ 凶e-mail: Lmedved@som.umaryland.edu
}

Фібриноген - поліфункціональний протеїн плазми крові, що бере участь в різних фізіологічних і патологічних процесах шляхом взаємодії своїх численних доменів із різними лігандами і клітинними рецепторами. Серед доменів фібриногену, два ВßN-домени утворені $\mathrm{N}$-кінцевими ділянками двох В $\beta$-ланцюгів, що включають амінокислотні залишки В $\beta 1-64$. Хоча сталого уявлення про їхню конформацію немає, а експерименти з рекомбінантним димерним (Вß1-66), фрагментом, який відповідає парі цих доменів, не виявили у ньому впорядкованої структури, деякі дані дозволяють припустити, що ці домени у нативній молекулі можуть бути просторово впорядковані. Проте, їхні основні функціональні властивості вивчено досить добре. Відщеплення фібринопептидів В (амінокислотні послідовності Вß1-14) від цих доменів у разі перетворення фібриногену у фібрин призводить до експозиції численних сайтів зв'язування у $\beta \mathrm{N}$-доменах фібрину (послідовність $\beta 15-64)$. Ці сайти забезпечують взаємодію $\beta \mathrm{N}$-доменів із різними протеїнами $\mathrm{i}$ клітинами, що обумовлює їхню участь у різних процесах, зокрема у самоскладанні фібрину, фібрин-залежному ангіогенезі, а також у фібринзалежній трансміграції лейкоцитів у процесі запалення. Метою цього огляду $є$ узагальнення сучасного уявлення про структуру та функції цих доменів фібриногену і фібрину та їхньої функціональної ролі. 
К л ю чо в і с ло ва: фібриноген, фібрин, $\beta \mathrm{N}$-домени, гепарин, VE-кадгерин, VLDLрецептор.

\section{References}

1. Henschen A, McDonagh J. Fibrinogen, fibrin and factor XIII. In: Zwaal RFA, Hemker HC (Eds.) Blood Coagulation. Elsevier Science Publishers, Amsterdam, 1986. P. 171-241.

2. Medved L, Weisel JW. Fibrinogen and Factor XIII Subcommittee of Scientific Standardization Committee of International Society on Thrombosis and Haemostasis. Recommendations for nomenclature on fibrinogen and fibrin. $J$ Thromb Haemost. 2009; 7(2): 355-359.

3. Privalov PL, Medved LV. Domains in the fibrinogen molecule. J Mol Biol. 1982; 159(4): 665-683.

4. Medved LV, Gorkun OV, Privalov PL. Structural organization of C-terminal parts of fibrinogen A $\alpha$-chains. FEBS Lett. 1983; 160(1-2): 291-295.

5. Medved' LV, Litvinovich SV, Privalov PL. Domain organization of the terminal parts in the fibrinogen molecule. FEBS Lett. 1986; 202(2): 298-302.

6. Medved L, Litvinovich S, Ugarova T, Matsukav Y, Ingham K. Domain structure and functional activity of the recombinant human fibrinogen $\gamma$-module ( $\gamma 148-411)$. Biochemistry. 1997; 36(15): 4685-4693.

7. Pratt KP, Côté HC, Chung DW, Stenkamp RE, Davie EW. The primary fibrin polymerization pocket: three-dimensional structure of a $30-\mathrm{kDa}$ C-terminal $\gamma$ chain fragment complexed with the peptide Gly-Pro-Arg-Pro. Proc Natl Acad Sci USA. 1997; 94(14): 7176-7181.

8. Spraggon G, Everse SJ, Doolittle RF. Crystal structures of fragment $\mathrm{D}$ from human fibrinogen and its crosslinked counterpart from fibrin. Nature. 1997; 389(6650): 455-462.

9. Brown JH, Volkmann N, Jun G, HenschenEdman AH, Cohen C. The crystal structure of modified bovine fibrinogen. Proc Natl Acad Sci USA. 2000; 97(1): 85-90.

10. Yang Z, Mochalkin I, Veerapandian L, Riley M, Doolittle RF. Crystal structure of native chicken fibrinogen at 5.5-Å resolution. Proc Natl Acad Sci USA. 2000; 97(8): 3907-3912.

11. Yang Z, Kollman JM, Pandi L, Doolittle RF. Crystal structure of native chicken fibrinogen at 2.7 A resolution. Biochemistry. 2001; 40(42): 12515-12523.

12. Madrazo J, Brown JH, Litvinovich S, Dominguez R, Yakovlev S, Medved L, Cohen C. Crystal structure of the central region of bovine fibrinogen $\left(\mathrm{E}_{5}\right.$ fragment) at $1.4-\AA$ resolution. Proc Natl Acad Sci USA. 2001; 98(21): 1196711972.

13. Pechik I,Madrazo J, Mosesson MW, Hernandez I, Gilliland GL, Medved L. Crystal structure of the complex between thrombin and the central "E" region of fibrin. Proc Natl Acad Sci USA. 2004; 101(9): 2718-2723.

14. Kollman JM, Pandi L, Sawaya MR, Riley M, Doolittle RF. Crystal structure of human fibrinogen. Biochemistry. 2009; 48(18): 38773886.

15. Burton RA, Tsurupa G, Medved L, Tjandra N. Identification of an ordered compact structure within the recombinant bovine fibrinogen $\alpha \mathrm{C}$ domain fragment by NMR. Biochemistry. 2006; 45(7): 2257-2266.

16. Burton RA, Tsurupa G, Hantgan RR, Tjandra N, Medved L. NMR solution structure, stability, and interaction of the recombinant bovine fibrinogen $\alpha \mathrm{C}$-domain fragment. Biochemistry. 2007; 46(29): 8550-8560.

17. Tsurupa G, Hantgan RR, Burton RA, Pechik I, Tjandra N, Medved L. Structure, stability, and interaction of the fibrin(ogen) $\alpha \mathrm{C}$-domains. Biochemistry. 2009; 48(51): 12191-12201.

18. Gorlatov S, Medved L. Interaction of fibrin(ogen) with the endothelial cell receptor VE-cadherin: mapping of the receptor-binding site in the $\mathrm{NH}_{2}$-terminal portions of the fibrin $\beta$ chains. Biochemistry. 2002; 41(12): 4107-4116.

19. Pandya BV, Gabriel JL, O'Brien J, Budzynski AZ. Polymerization site in the $\beta$ chain of fibrin: mapping of the B $\beta 1-55$ sequence. Biochemistry. 1991; 30(1): 162-168.

20. Chernyshenko VO, Volynets GP. Predicting of fibrinogen $\mathrm{B} \beta \mathrm{N}$-domain conformation by computer modeling and limited proteolysis. $U \mathrm{kr}$ Bioorg Acta. 2011; 9(1): 53-57.

21. Litvinov RI, Yakovlev S, Tsurupa G, Gorkun OV, Medved L, Weisel JW. Direct evidence for specific interactions of the fibrinogen $\alpha \mathrm{C}$ domains with the central $\mathrm{E}$ region and with each other. Biochemistry. 2007; 46(31): 9133-9142.

22. Blomback B, Blomback $M$, Nilsson IM. Coagulation studies on "Reptilase", an extract 
of the venom from Bothrops jararaca. Thromb Diath Haemorrh. 1958; 1(1): 76-86.

23. Weisel JW, Litvinov RI. Mechanisms of fibrin polymerization and clinical implications. Blood. 2013; 121(10): 1712-1719.

24. Collet JP, Park D, Lesty C, Soria J, Soria C, Montalescot G, Weisel JW. Influence of fibrin network conformation and fibrin fiber diameter on fibrinolysis speed: dynamic and structural approaches by confocal microscopy. Arterioscler Thromb Vasc Biol. 2000; 20(5): 1354-1361.

25. Collet JP, Lesty C, Montalescot G, Weisel JW. Dynamic changes of fibrin architecture during fibrin formation and intrinsic fibrinolysis of fibrin-rich clots. J Biol Chem. 2003; 278(24): 21331-21335.

26. Weisel JW, Veklich Y, Gorkun O. The sequence of cleavage of fibrinopeptides from fibrinogen is important for protofibril formation and enhancement of lateral aggregation in fibrin clots. J Mol Biol. 1993; 232(1): 285-297.

27. Yang Z, Mochalkin I, Doolittle RF. A model of fibrin formation based on crystal structures of fibrinogen and fibrin fragments complexed with synthetic peptides. Proc Natl Acad Sci USA. 2000; 97(26): 14156-14161.

28. Everse SJ, Spraggon G, Veerapandian L, Riley M, Doolittle RF. Crystal structure of fragment double-D from human fibrin with two different bound ligands. Biochemistry. 1998; 37(24): 8637-8642.

29. Laudano AP, Doolittle RF. Synthetic peptide derivatives that bind to fibrinogen and prevent the polymerization of fibrin monomers. Proc Natl Acad Sci USA. 1978; 75(7): 3085-3089.

30. Laudano AP, Cottrell BA, Doolittle RF. Synthetic peptides modeled on fibrin polymerization sites. Ann N Y Acad Sci. 1983; 408: 315-329.

31. Blombäck B, Hessel B, Hogg D, Therkildsen L. A two-step fibrinogen-fibrin transition in blood coagulation. Nature. 1978; 275(5680): 501-505.

32. Weisel JW. Fibrinogen and fibrin. Adv Protein Chem. 2005; 70: 247-299.

33. Martinelli RA, Scheraga HA. Steady-state kinetic study of the bovine thrombin-fibrinogen interaction. Biochemistry. 1980; 19(11): 23432350.

34. Hurlet-Jensen A, Cummins HZ, Nossel HL, Liu CY. Fibrin polymerization and release of fibrinopeptide B by thrombin. Thromb Res. 1982; 27(4): 419-427.
35. Higgins DL, Lewis SD, Shafer JA. Steady state kinetic parameters for the thrombin-catalyzed conversion of human fibrinogen to fibrin. $J$ Biol Chem. 1983; 258(15): 9276-9282.

36. Pechik I, Yakovlev S, Mosesson MW, Gilliland GL, Medved L. Structural basis for sequential cleavage of fibrinopeptides upon fibrin assembly. Biochemistry. 2006; 45(11): 3588-3597.

37. Iozzo RV. Matrix proteoglycans: from molecular design to cellular function. Annu Rev Biochem. 1998; 67: 609-652.

38. Bernfield M, Götte M, Park PW, Reizes O, Fitzgerald ML, Lincecum J, Zako M. Functions of cell surface heparan sulfate proteoglycans. Annu Rev Biochem. 1999; 68: 729-777.

39. Sasisekharan R, Venkataraman G. Heparin and heparan sulfate: biosynthesis, structure and function. Curr Opin Chem Biol. 2000; 4(6): 626631.

40. Esko JD, Lindahl U. Molecular diversity of heparan sulfate. J Clin Invest. 2001; 108(2): 169173.

41. Scully MF, Ellis V, Kakkar VV. Localisation of heparin in mast cells. Lancet. 1986; 2(8509): 718-719.

42. Capila I, Linhardt RJ. Heparin-protein interactions. Angew Chem Int Ed Engl. 2002; 41(3): 391-412.

43. Whinna HC, Church FC. Interaction of thrombin with antithrombin, heparin cofactor II, and protein C inhibitor. J Protein Chem. 1993; 12(6): 677-688.

44. Li W, Johnson DJ, Esmon CT, Huntington JA. Structure of the antithrombin-thrombin-heparin ternary complex reveals the antithrombotic mechanism of heparin. Nat Struct Mol Biol. 2004; 11(9): 857-862.

45. Hogg PJ, Jackson CM. Formation of a ternary complex between thrombin, fibrin monomer, and heparin influences the action of thrombin on its substrates. J Biol Chem. 1990; 265(1): 248255.

46. Hogg PJ, Jackson CM. Fibrin monomer protects thrombin from inactivation by heparinantithrombin III: implications for heparin efficacy. Proc Natl Acad Sci USA. 1989; 86(10): 3619-3623.

47. Hogg PJ, Jackson CM. Heparin promotes the binding of thrombin to fibrin polymer. Quantitative characterization of a thrombin- 
fibrin polymer-heparin ternary complex. $J$ Biol Chem. 1990; 265(1): 241-247.

48. Hogg PJ, Bock PE. Modulation of thrombin and heparin activities by fibrin. Thromb Haemost. 1997; 77(3): 424-433.

49. Odrljin TM, Francis CW, Sporn LA, Bunce LA, Marder VJ, Simpson-Haidaris PJ. Heparinbinding domain of fibrin mediates its binding to endothelial cells. Arterioscler Thromb Vasc Biol. 1996; 16(12): 1544-1551.

50. Retzinger GS, Chandler LJ, Cook BC. Complexation with heparin prevents adhesion between fibrin-coated surfaces. $J$ Biol Chem. 1992; 267(34): 24356-24362.

51. Mohri H, Ohkubo T. Fibrinogen binds to heparin: the relationship of the binding of other adhesive proteins to heparin. Arch Biochem Biophys. 1993; 303(1): 27-31.

52. Raut S, Gaffney PJ. Interaction of heparin with fibrinogen using surface plasmon resonance technology: investigation of heparin binding site on fibrinogen. Thromb Res. 1996; 81(4): 503-509.

53. Odrljin TM, Shainoff JR, Lawrence SO, Simpson-Haidaris PJ. Thrombin cleavage enhances exposure of a heparin binding domain in the N-terminus of the fibrin $\beta$ chain. Blood. 1996; 88(6): 2050-2061.

54. Mohri H, Iwamatsu A, Ohkubo T. Heparin binding sites are located in a $40-\mathrm{kD} \gamma$-chain and a $36-\mathrm{kD} \beta$-chain fragment isolated from human fibrinogen. J Thromb Thrombolysis. 1994; 1(1): 49-54.

55. Skogen WF, Wilner GD. A simple one-step HPLC procedure for the purification of the $\mathrm{NH}_{2}-$ terminal plasmin-derived $\mathrm{B} \beta$ 1-42 peptide of human fibrinogen. Thromb Res. 1986; 41(2): 161166.

56. Pandya BV, Rubin RN, Olexa SA, Budzynski AZ. Unique degradation of human fibrinogen by proteases from western diamondback rattlesnake (Crotalus atrox) venom. Toxicon. 1983; 21(4): 515-526.

57. Pandya BV, Budzynski AZ. Anticoagulant proteases from western diamondback rattlesnake (Crotalus atrox) venom. Biochemistry. 1984; 23(3): 460-470.

58. Pandya BV, Cierniewski CS, Budzynski AZ. Conservation of human fibrinogen conformation after cleavage of the $\mathrm{B} \beta$ chain $\mathrm{NH}_{2}$ terminus. $J$ Biol Chem. 1985; 260(5): 2994-3000.

59. Yakovlev S, Gorlatov S, Ingham K, Medved L. Interaction of fibrin(ogen) with heparin: further characterization and localization of the heparinbinding site. Biochemistry. 2003; 42(25): 77097716.

60. Brasch J, Harrison OJ, Honig B, Shapiro L. Thinking outside the cell: how cadherins drive adhesion. Trends Cell Biol. 2012; 22(6): 299-310.

61. Martinez J, Ferber A, Bach TL, Yaen CH. Interaction of fibrin with VE-cadherin. Ann NY Acad Sci. 2001; 936: 386-405.

62. Folkman J. Angiogenesis in cancer, vascular, rheumatoid and other disease. Nat Med. 1995; 1(1): 27-31.

63. Ware JA, Simons M. Angiogenesis in ischemic heart disease. Nat Med. 1997; 3(2): 158-164.

64. Tonnesen MG, Feng X, Clark RA. Angiogenesis in wound healing. $J$ Investig Dermatol Symp Proc. 2000; 5(1): 40-46.

65. Conway EM, Collen D, Carmeliet P. Molecular mechanisms of blood vessel growth. Cardiovasc Res. 2001; 49(3): 507-521.

66. Montesano R, Pepper MS, Vassalli JD, Orci L. Phorbol ester induces cultured endothelial cells to invade a fibrin matrix in the presence of fibrinolytic inhibitors. J Cell Physiol. 1987; 132(3): 509-516.

67. Nicosia RF, Ottinetti A. Modulation of microvascular growth and morphogenesis by reconstituted basement membrane gel in threedimensional cultures of rat aorta: a comparative study of angiogenesis in matrigel, collagen, fibrin, and plasma clot. In Vitro Cell Dev Biol. 1990; 26(2): 119-128.

68. Chalupowicz DG, Chowdhury ZA, Bach TL, Barsigian C, Martinez J. Fibrin II induces endothelial cell capillary tube formation. $J$ Cell Biol. 1995; 130(1): 207-215.

69. Bach TL, Barsigian C, Chalupowicz DG, Busler D, Yaen CH, Grant DS, Martinez J. VEcadherin mediates endothelial cell capillary tube formation in fibrin and collagen gels. Exp Cell Res. 1998; 238(2): 324-334.

70. Bach TL, Barsigian C, Yaen CH, Martinez J. Endothelial cell VE-cadherin functions as a receptor for the $\beta 15-42$ sequence of fibrin. $J$ Biol Chem. 1998; 273(46): 30719-30728.

71. Procyk R, Kudryk B, Callender S, Blombäck B. Accessibility of epitopes on fibrin clots and fibrinogen gels. Blood. 1991; 77(7): 1469-1475.

72. Harris ES, Nelson WJ. VE-cadherin: at the front, center, and sides of endothelial cell organization and function. Curr Opin Cell Biol. 2010; 22(5): 651-658. 
73. Dejana E, Tournier-Lasserve E, Weinstein BM. The control of vascular integrity by endothelial cell junctions: molecular basis and pathological implications. Dev Cell. 2009; 16(2): 209-221.

74. Yakovlev S, Medved L. Interaction of fibrin(ogen) with the endothelial cell receptor VE-cadherin: localization of the fibrin-binding site within the third extracellular VE-cadherin domain. Biochemistry. 2009; 48(23): 5171-5179.

75. Petzelbauer P, Zacharowski PA, Miyazaki Y, Friedl P, Wickenhauser G, Castellino FJ, Gröger M, Wolff K, Zacharowski K. The fibrin-derived peptide $\mathrm{B} \beta 15-42$ protects the myocardium against ischemia-reperfusion injury. Nat Med. 2005; 11(3): 298-304.

76. Zacharowski K, Zacharowski P, Reingruber S, Petzelbauer P. Fibrin(ogen) and its fragments in the pathophysiology and treatment of myocardial infarction. J Mol Med (Berl). 2006; 84(6): 469477.

77. Yakovlev S, Gao Y, Cao C, Chen L, Strickland DK, Zhang L, Medved L. Interaction of fibrin with VE-cadherin and anti-inflammatory effect of fibrin-derived fragments. J Thromb Haemost. 2011; 9(9): 1847-1855.

78. Yakovlev S, Cao C, Galisteo R, Zhang L, Strickland DK, Medved L. Fibrin-VLDL receptor-dependent pathway promotes leukocyte transmigration by inhibiting Src kinase Fyn and is a target for fibrin $\beta 15-42$ peptide. Thromb Haemost. 2019; 119(11): 1816-1826.

79. Yakovlev S, Mikhailenko I, Cao C, Zhang L, Strickland DK, Medved L. Identification of VLDLR as a novel endothelial cell receptor for fibrin that modulates fibrin-dependent transendothelial migration of leukocytes. Blood. 2012; 119(2): 637-644.

80. Yakovlev S, Medved L. Effect of fibrinogen, fibrin, and fibrin degradation products on transendothelial migration of leukocytes. Thromb Res. 2018; 162: 93-100.

81. Yakovlev S, Medved L. Interaction of fibrin with the very low-density lipoprotein (VLDL) receptor: further characterization and localization of the VLDL receptor-binding site in fibrin $\beta \mathrm{N}$-domains. Biochemistry. 2017; 56(19): 2518-2528.

82. Yakovlev S, Medved L. Interaction of fibrin with the very low density lipoprotein receptor: further characterization and localization of the fibrin-binding site. Biochemistry. 2015; 54(30): 4751-4761.

83. Banerjee K, Yakovlev S, Gruschus JM, Medved L, Tjandra N. Nuclear magnetic resonance solution structure of the recombinant fragment containing three fibrin-binding cysteine-rich domains of the very low density lipoprotein receptor. Biochemistry. 2018; 57(30): 4395-4403.

84. Holinstat M, Knezevic N, Broman M, Samarel AM, Malik AB, Mehta D. Suppression of RhoA activity by focal adhesion kinaseinduced activation of p190RhoGAP: role in regulation of endothelial permeability. $\mathrm{J}$ Biol Chem. 2006; 281(4): 2296-2305.

85. Gröger M, Pasteiner W, Ignatyev G, Matt U, Knapp S, Atrasheuskaya A, Bukin E, Friedl P, Zinkl D, Hofer-Warbinek R, Zacharowski K, Petzelbauer P, Reingruber S. Peptide B $\beta 15-42$ preserves endothelial barrier function in shock. PLoS One. 2009; 4(4): e5391.

86. Yakovlev S, Belkin AM, Chen L, Cao C, Zhang L, Strickland DK, Medved L. Anti-VLDL receptor monoclonal antibodies inhibit fibrin-VLDL receptor interaction and reduce fibrin-dependent leukocyte transmigration. Thromb Haemost. 2016; 116(6): 1122-1130.

87. Ruiz J, Kouiavskaia D, Migliorini M, Robinson S, Saenko EL, Gorlatova N, Li D, Lawrence D, Hyman BT, Weisgraber KH, Strickland DK. The apoE isoform binding properties of the VLDL receptor reveal marked differences from LRP and the LDL receptor. J Lipid Res. 2005; 46(8): 1721-1731. 